\title{
Isolated Perianal Erosive Lichen Planus: A Diagnostic Challenge
}

\author{
Marely Santiago, MD; Oscar Nevarez, MD; Leyre Falto-Aizpurua, MD; Nicole Candelario, MD; \\ Francisco Colon-Fontanez, MD
}

\section{PRACTICE POINTS}

- Erosive lichen planus (LP) is an underrecognized variant of LP presenting with painful erosions, ulcerations, and scarring.

- Although rare, perianal erosive LP should be included in the differential diagnosis of perianal erosions.

- Treatment with high-potency steroids is an effective therapeutic option resulting in notable improvement.

To the Editor:

Erosive lichen planus (LP) often is painful, debilitating, and resistant to topical therapy making it both a diagnostic and therapeutic challenge. We report the case of an elderly woman with isolated perianal erosive LP, a rare clinical manifestation. We also review cases of erosive perianal LP reported in the literature.

A 72-year-old woman was referred to our dermatology clinic for evaluation of multiple pruritic and painful perianal lesions of 1 year's duration. The lesions had remained stable since onset, with no other reported lesions elsewhere on body, including the mucosae. Her medical history was notable for rheumatoid arthritis, osteoporosis, hypercholesterolemia, and hypertension. She was taking methotrexate, folic acid, abatacept, alendronate, atorvastatin, and lisinopril. The patient reported she had been using abatacept for 3 years and lisinopril for 2 years. Her primary care physician initially treated the lesions as hemorrhoids but referred her to a gastroenterologist when they failed to improve. Gastroenterology evaluated the patient, and a colonoscopy was performed with unremarkable results. Thus, she was referred to dermatology for further evaluation.

Physical examination revealed 2 tender, sharply defined, angulated erosions with irregular violaceous borders involving the perianal skin (Figure 1). A biopsy of one of the lesions was taken. Histopathologic examination revealed acanthosis of the epidermis with slight compact hyperkeratosis, scattered dyskeratotic keratinocytes, and a dense bandlike lymphohistiocytic infiltrate that obliterated the dermoepidermal junction (Figure 2). A diagnosis of perianal erosive LP was made. The patient

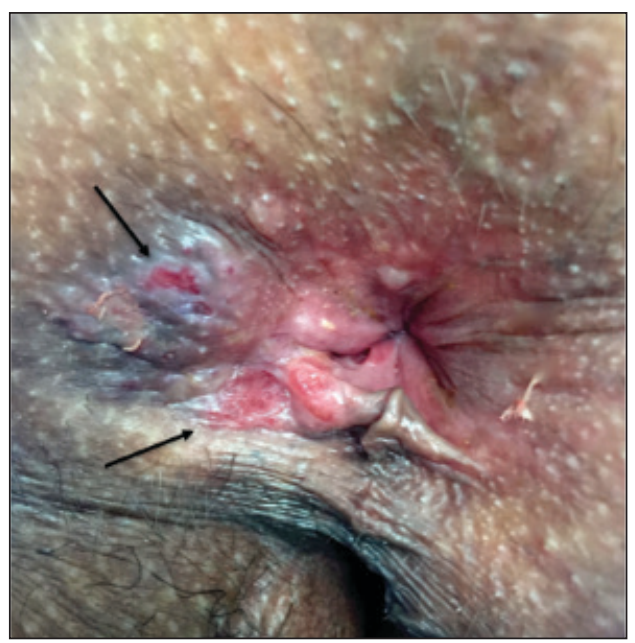

FIGURE 1. Sharply defined and angulated erosions with irregular borders (arrows).

Drs. Santiago, Nevarez, Falto-Aizpurua, and Colon-Fontanez are from the Department of Dermatology, University of Puerto Rico, Medical Sciences Campus, San Juan. Dr. Candelario is from Hato Rey Pathology Associates, Inc, San Juan.

The authors report no conflict of interest.

Correspondence: Leyre Falto-Aizpurua, MD, Department of Dermatology, University of Puerto Rico, PO Box 365067, San Juan PR $00936-5067$ (lafalto@gmail.com).

doi:10.12788/cutis.0229 
was prescribed mometasone ointment $0.1 \%$ daily with notable improvement after 2 months.

Erosive LP is an extremely rare variant of LP. ${ }^{1}$ It typically manifests as chronic painful erosions that often can progress to scarring, ulceration, and tissue destruction. Although erosive LP most commonly involves the mucosal surfaces of the genitalia and oral mucosa, it also has been reported in the palmoplantar skin, lacrimal duct, external auditory meatus, and esophagus. ${ }^{2-7}$ However, isolated perianal involvement is extremely rare. A PubMed search of articles indexed for MEDLINE using the terms erosive or ulcerative and lichen planus and perianal revealed 10 cases of perianal erosive LP, and weak data exist regarding therapy (Table). ${ }^{8-12}$ Of these
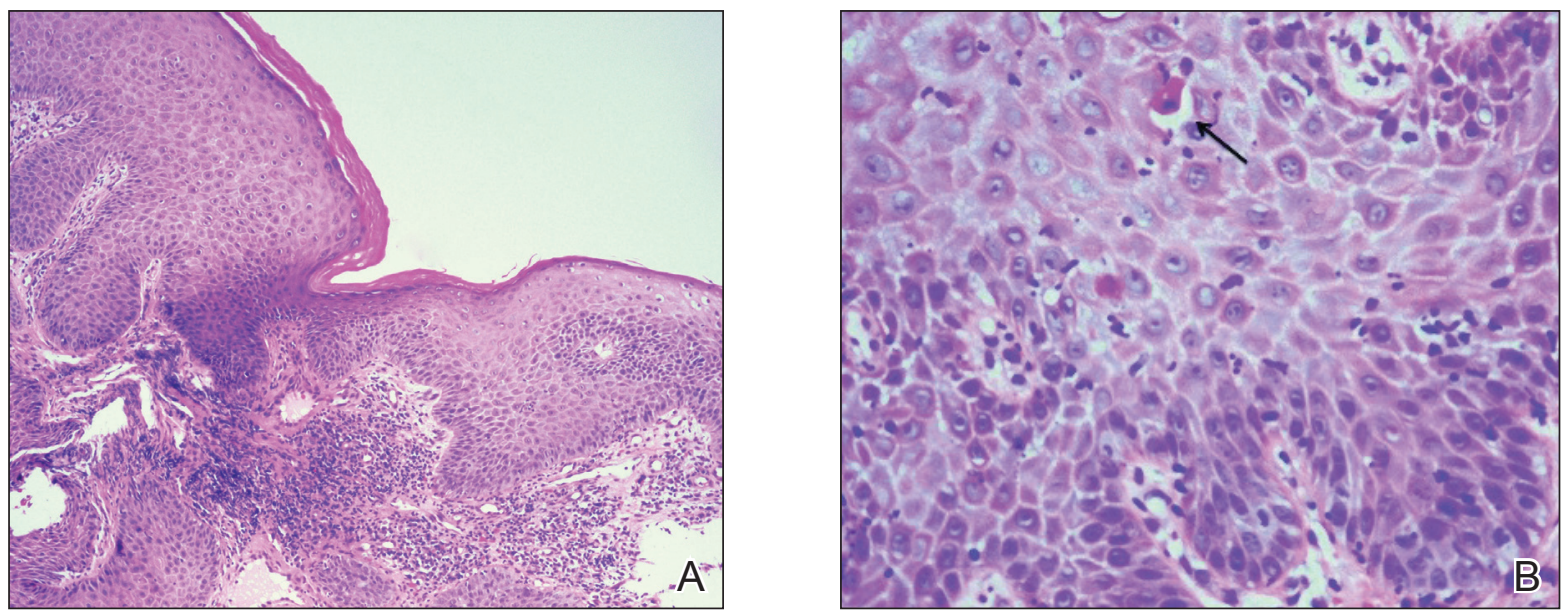

FIGURE 2. A, Histopathologic examination revealed acanthosis of the epidermis with slight compact hyperkeratosis, scattered dyskeratotic keratinocytes, and a dense bandlike lymphohistiocytic infiltrate that obliterated the dermoepidermal junction (H\&E, original magnification $\times 10)$. B, A Civatte body was observed (arrow)(H\&E, original magnification $\times 20)$.

\section{Summary of Cases of Erosive Perianal Lichen Planus}

\begin{tabular}{|c|c|c|c|c|c|c|}
\hline $\begin{array}{l}\text { Reference } \\
\text { (year) }\end{array}$ & Age, y & Sex & Location & $\begin{array}{l}\text { Time of } \\
\text { evolution }\end{array}$ & Treatment & Comments \\
\hline $\begin{array}{l}\text { Payne et al } \\
\text { (1997) }\end{array}$ & $35-60$ & & $\begin{array}{l}1 \text { case isolated to } \\
\text { the perianal region; } \\
\text { the other cases not } \\
\text { specified if perianal on }\end{array}$ & 6 wk to $8 y$ & $\begin{array}{l}\text { Clobetasol propionate } \\
\text { ointment } 0.05 \% \text { BID } \\
\text { for } 3 \text { wk }\end{array}$ & Good response \\
\hline $\begin{array}{l}\text { Watsky et al }{ }^{9} \\
\text { (2003) }\end{array}$ & 46 & $M$ & Perianal region & $2-3 y$ & $\begin{array}{l}\text { Halobetasol ointment } \\
\text { for } 10 \text { wk, recurred } \\
1 \text { year later; then } \\
\text { tacrolimus ointment } \\
0.1 \% \text { for } 1 \mathrm{mo} \text {, no } \\
\text { recurrence }\end{array}$ & $\begin{array}{l}\text { Folliculitis } \\
\text { developed after } \\
\text { halobetasol, } \\
\text { treated with topical } \\
\text { clindamycin }\end{array}$ \\
\hline $\begin{array}{l}\text { Scheiba et al }{ }^{10} \\
(2014)\end{array}$ & 49 & M & Perianal region & Several months & NR & $\begin{array}{l}\text { Hypertrophic, } \\
\text { slightly erosive } \\
\text { perianal LP }\end{array}$ \\
\hline $\begin{array}{l}\text { Wu et } \mathrm{al}^{11} \\
(2014)\end{array}$ & 32 & $\mathrm{~F}$ & $\begin{array}{l}\text { Gums, vulva, } \\
\text { perianal region }\end{array}$ & $8 y$ & $\begin{array}{l}\text { Topical tacrolimus } \\
\text { for } 3 \text { wk with notable } \\
\text { improvement }\end{array}$ & $\begin{array}{l}\text { Vulvovaginal } \\
\text { gingival syndrome }\end{array}$ \\
\hline $\begin{array}{l}\text { Hammami et al }{ }^{12} \\
\text { (2015) }\end{array}$ & 52 & $M$ & $\begin{array}{l}\text { Tongue, glans penis, } \\
\text { perianal region }\end{array}$ & Days (NS) & Systemic steroids & $\begin{array}{l}\text { LP induced by } \\
\text { glimepiride }\end{array}$ \\
\hline Current case & 72 & F & Perianal region & $1 \mathrm{y}$ & $\begin{array}{l}\text { Mometasone } \\
\text { ointment } 0.1 \%\end{array}$ & Clinical remission \\
\hline
\end{tabular}

Abbreviations: M, male; F, female; BID, twice daily; NR, not reported; LP, lichen planus; NS, not specified. 
cases, only 3 reported isolated perianal involvement. ${ }^{8-10}$ In most reported cases, perianal involvement manifested as extremely painful and occasionally pruritic, sharply angulated erosions and ulcers arising 0.5 to $3 \mathrm{~cm}$ from the anus with macerated, whitish, and violaceous borders. Most of the lesions occurred unilaterally, with only 1 case of bilateral perianal involvement. ${ }^{10}$

The differential diagnosis of perianal erosions is extensive and includes cutaneous Crohn disease, extramammary Paget disease, cutaneous malignancy, herpes simplex virus, cytomegalovirus, external hemorrhoids, lichen sclerosus, Behçet disease, lichen simplex chronicus, and drug-induced lichenoid reaction, among others. It is worth emphasizing infectious processes and cutaneous malignancies in light of our patient's immunosuppression. Perianal cytomegalovirus has been reported in the literature in association with HIV, and it is a clinically challenging diagnosis. ${ }^{13}$ Cutaneous malignancy associated with the use of methotrexate also was considered in the differential diagnosis for our patient, given the increased risk for nonmelanoma skin cancer with the use of immunosuppresants. ${ }^{14}$

Along with a thorough patient history and physical examination, skin biopsy and clinicopathologic correlation are key to determine the exact etiology. Histologically, LP is characterized by a lichenoid interface dermatitis with a dense bandlike lymphohistiocytic infiltrate at the dermoepidermal junction. Other distinguishing factors include irregular acanthosis, hyperkeratosis, basal cell vacuolar degeneration, and Civatte bodies. Drug-induced LP is a possibility, but it is unclear if abatacept or lisinopril may have played a role in our patient. However, absence of eosinophils and parakeratosis suggested an idiopathic rather than drug-induced etiology. In 2016, Day et $\mathrm{al}^{2}$ published a clinicopathologic review of 60 cases of perianal lichenoid dermatoses in which only $17 \%$ of lesions were LP. Of note, $90 \%$ of perianal LP lesions were of the hypertrophic variant, and none were of the erosive variant, further supporting that our case represents a rare clinical manifestation of perianal LP.

Treatment of LP varies depending on the location and subtype of the lesions and is primarily aimed at improving symptoms. Topical corticosteroids are the standard treatment of LP; however, there is limited evidence regarding their efficacy for mucosal LP. Although randomized controlled trials assessing the efficacy of different interventions on oral erosive LP are available in the literature, ${ }^{15}$ there is a paucity of studies addressing this topic for genital or perianal LP. A review of the literature regarding perianal erosive LP suggests good response to high-potency topical steroids and calcineurin inhibitors with resolution of lesions within 3 to 4 weeks. ${ }^{11,15-18}$

Erosive LP is a painful variant that can cause erosions, ulcerations, and scarring. It rarely is seen in the perianal region alone and presents a diagnostic challenge. Treatment with high-potency topical steroid therapy seems to be effective in the few cases that have been reported as well as in our case. More comprehensive data from randomized controlled trials would be needed to evaluate their efficacy compared to other therapies.

\section{REFERENCES}

1. Rebora A. Erosive lichen planus: what is this? Dermatology. 2002;205:226-228; discussion 227.

2. Day T, Bohl TG, Scurry J. Perianal lichen dermatoses: a review of 60 cases. Australas J Dermatol. 2016;57:210-215.

3. Fox LP, Lightdale CJ, Grossman ME. Lichen planus of the esophagus: what dermatologists need to know. J Am Acad Dermatol. 2011;65:175-883.

4. Holmstrup P, Thorn JJ, Rindum J, et al. Malignant development of lichen planus-affected oral mucosa. J Oral Pathol. 1988;17:219-225.

5. Lewi, FM, Bogliatto F. Erosive vulval lichen planus-a diagnosis not to be missed: a clinical review. Eur J Obstet Gynecol Reprod Biol. 2013;171:214-219.

6. Webber NK, Setterfield JF, Lewis FM, et al. Lacrimal canalicular duct scarring in patients with lichen planus. Arch Dermatol. 2012;148:224-227.

7. Martin L, Moriniere S, Machet MC, et al. Bilateral conductive deafness related to erosive lichen planus. J Laryngol Otol. 1998;112:365-366.

8. Payne CM, McPartlin JF, Hawley PR. Ulcerative perianal lichen planus. Br J Dermatol. 1997;136:479.

9. Watsky KL. Erosive perianal lichen planus responsive to tacrolimus. Int J Dermatol. 2003;42:217-218.

10. Scheiba N, Toberer F, Lenhard BH, et al. Erythema and erosions of the perianal region in a 49 -year-old man. J Dtsch Dermatol Ges. 2014;12:162-165.

11. Wu Y, Qiao J, Fang H. Syndrome in question. An Bras Dermatol. 2014;89:843-844.

12. Hammami S, Ksouda K, Affes H, et al. Mucosal lichenoid drug reaction associated with glimepiride: a case report. Eur Rev Med Pharmacol Sci. 2015;19:2301-2302.

13. Meyerle JH, Turiansky GW. Perianal ulcer in a patient with AIDS. Arch Dermatol. 2004;140:877-882.

14. Scott FI, Mamtani R, Brensinger CM, et al. Risk of nonmelanoma skin cancer associated with the use of immunosuppressant and biologic agents in patients with a history of autoimmune disease and nonmelanoma skin cancer. JAMA Dermatol. 2016;152:164-172.

15. Cheng S, Kirtschig G, Cooper S, et al. Interventions for erosive lichen planus affecting mucosal sites. Cochrane Database Syst Rev. 2012:Cd008092.

16. Gunther S. Effect of retinoic acid in lichen planus of the genitalia and perianal region. Br J Vener Dis. 1973;49:553-554.

17. Vente C, Reich K, Neumann C. Erosive mucosal lichen planus: response to topical treatment with tacrolimus. $\mathrm{Br} J$ Dermatol. 1999;140:338-342.

18. Lonsdale-Eccles AA, Velangi S. Topical pimecrolimus in the treatment of genital lichen planus: a prospective case series. Br J Dermatol. 2005;153:390-394. 